\title{
FISTULOTOMY FOR THE SURGICAL TREATMENT OF PERIANAL FISTULA OF CRYPTOGLANDULAR ORIGIN
}

\author{
Evangelos Xynos \\ Colorectal Unit, Creta Interclinic Hospital, Crete, Greece
}

\begin{abstract}
Perianal fistula usually results from a non-specific infection of the cryptic glands located at the anal dentate line. Identification of the exact course of a perianal fistula and the extent of anal sphincteric complex involvement are of paramount importance, in order to design the therapeutic and interventional approach and achieve the best results without impairment of the anorectal function. Several interventional methods are in use for the surgical treatment of CPF, including fistulotomy, insertion of cutting "seton", core fistulectomy, ligation of the intersphincteric fistulous track (LIFT), rectal advancement flap, injection of fibrin glue at the fistulous track, insertion of fistulous plug, and obliteration of the fistulous track with the use of Laser. In clinical practice a combination of the aforementioned methods can be used, in particular for the complex-high or recurrent fistulae.
\end{abstract}

Key words: perianal fistula, fistulotomy, anal sphincter.

\section{Introduction}

Perianal fistula usually results from a non-specific infection of the cryptic glands located at the anal dentate line. Other less common causes are infection from unusual bacteria, inflammatory bowel disease - mostly Crohn's, malignancy, trauma and radiation of the perianal area [1-4]. According to the course through the anal and perineal musculature to their origin at the dentate line, Parks et al. [5] classified perianal fistulas as subcutaneous-superficial, intersphincteric (coursing between internal and external sphincter), transphincteric (coursing through the external sphincter and internal sphincters), suprasphincteric (coursing over the puborectalis) and extrasphincteric, the latter usually different to cryptoglandular sepsis etiology. More recently, perianal fistulae are classified as low (involvement of the distal third of the sphincteric complex) and high (involvement of the middle or/and the upper third of the sphincteric complex) (Fig. 1). In addition, low and high perianal fistulae are classified as simple and branching [6].

\section{Diagnostic Methods}

Identification of the exact course of a perianal fistula and the extent of anal sphincteric complex involvement are of paramount importance, in order to design the therapeutic and interventional approach and achieve the best results without impairment of the anorectal function. Magnetic resonance imaging (MRI) is considered the gold standard diagnostic tool for the assessment of cryptoglandular perianal fistulae (CPF), in particular the high ones, with

Correspondence to: Evangelos Xynos, M.D., Ph.D.

Colorectal Unit, Creta Interclinic Hospital,

Minoos 63, Heraklion Crete, Greece, P.O. 71304

Phone: +302810373800

E-mail: exynos@gmail.com

Received May $7^{\text {th }}, 2019$ accuracy rates above 90\% [7-10]. Also, valuable information for high, complex and recurrent CPF can be obtained with the use of three-dimensional endosonography. Accuracy rate of this modality ranges from $50 \%$ to $100 \%$, depending on the examiner's expertise [10-15]. Combination of both modalities increases accuracy [10].

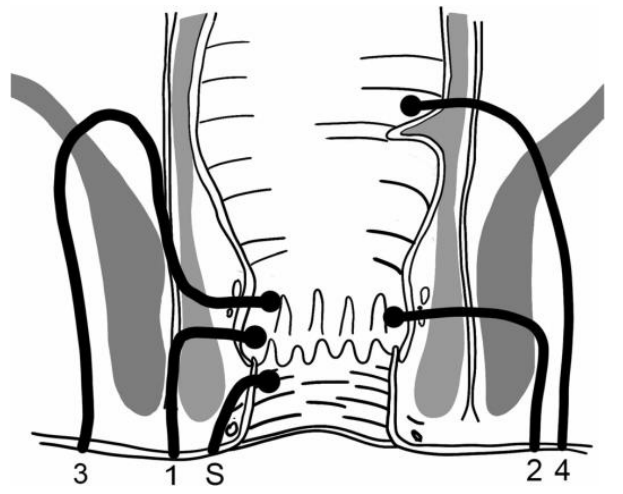

Fig. 1 Diagrammatic representation of the Park's classification of perianal fistula. S: sabcutaneoussuperficial; 1: intersphincteric; 2: transsphincteric; 3: suprasphincteric; 4: extrasphincteric [5].

\section{Treatment}

Several interventional methods are in use for the surgical treatment of CPF, including fistulotomy [16-18], insertion of cutting "seton" [19-21] or loose "seton" [21-23], core fistulectomy [24], ligation of the intersphincteric fistulous track (LIFT) [25], rectal advancement flap [26-30], injection of fibrin glue at the fistulous track [23,31,32], insertion of fistulous plug $[33,34]$, and obliteration of the fistulous track with the use of Laser [35-37]. In clinical practice a combination 
of the aforementioned methods can be used, in particular for the complex-high or recurrent fistulae.

\section{Fistulotomy for the Low CPF}

Despite some discrepancies in the indications among several guidelines [10], fistulotomy (FT) is the most common method for the surgical treatment of CPF. The main indications of FT are the superficial-subcutaneous, intersphincteric and low transsphincteric (involving less than $30 \%$ of the anal sphincter complex) CRF $[9,10$, 14,38]. Relative contraindications of FT for intersphincteric and low transsphincteric CPF are i) preoperative impairment of continence, ii) multiparous female with marginal fecal continence, iii) previous surgery, iv) recurrent CRF after fistulotomy, and v) Crohn's disease. Absolute contraindications of FT as the sole treatment are high transsphincteric, suprasphincteric and extrasphincteric CPF [10,39-41].

As regards the operative technique, under general anesthesia and the guidance of preoperative imaging assessment, i) the external opening is visualized, ii) the internal opening at the dentate line is identified with the injection of methylene blue through the external opening, iii) any branching of the fistula is also sought and identified, iv) a probe is gently inserted from the external opening, through the fistulous track to the internal opening at the dentate line, and v) the FT is carried out in a lay-open fashion with the use of a scalpel or electrocautery.

FT for the simple and low CPF is associated with high success rate, ranging from $80 \%$ to $100 \%$, at the immediate follow-up [41-44]. Garces-Albir et al [13] report no recurrence after FT for simple and low CPF at one-year postoperatively, provided the extent of fistulotomy had been quantified preoperatively with threedimensional endosonography. Cariati [45] reports $100 \%$ healing rate after FT for low CPF involving $\leq 10 \%$ of the distal external anal sphincter, at 6 months. Interestingly, van der Hagen et al [46] report that success rate of FT for low CRF decreases by time; from $93 \%$ at 12-month postoperatively to $74 \%$ and $61 \%$ at 48 - and 72 -month postoperatively. It is stated that recurrence can be either the result of treatment failure because of overlooked fistula branching or recurrent patient disease, as fistula recurrence occurs at different location in $54 \%$ of the cases. Patient predisposition may explain the latter observation, as it has been shown that there is an increased expression of pro-inflammatory cytokines and epithelial-to-mesenchymal cell transition in CPF. Therefore, molecular mechanisms may also interfere in pathogenesis and also persistence of CPF [47].

Some degree of incontinence, usually in the form of mucous discharge, is reported by more than $30 \%$ of the patients after FT $[41,43,48]$. Incontinence is minimal when FT is limited to the distal anal sphincter complex, and increases in parallel to the length of the external anal sphincter division [13]. Impairment of continence after FT is also related to preoperative functional status $[41,43]$.

\section{Complementary FT for High CPF}

FT may be part of the surgical treatment of high and complex CRF. Chatterjee et al [49] combined partial FT (from the external opening to the level of the dentate line) with cutting "seton" passing through the deep fistulous track in 16 patients with high CPF. They observed one recurrence and incontinence to flatus in one patient. A similar surgical approach was applied by Durgun et al [50] in 10 patients with high CPF, with no recurrence and only two patients complaining of incontinence to flatus.

Fung et al [51] performed partial FT of the subcutaneous part of the fistulous track and placed a loose seton through the fistulous track involving the sphincter complex in 46 patients with high CPF. They report a healing rate of $86 \%$ and a recurrence rate of $19 \%$, at a median follow-up of 42 months. Finally, Schultze and Ho [52], treated 75 patients with high and complex CPF with a staged approach: at the first stage they performed FT involving the subcutaneous part of the fistulous track and placed a loose "seton" through the fistulous track involving the sphincter complex and, at the second stage four months later, they performed a LIFT procedure. They observed a recurrence rate of $12 \%$, mostly attributed to incomplete identification and drainage of the fistulous track branching, and minor incontinence in one patient.

\section{Conclusions}

Prior to surgical intervention for the treatment of CPF, image identification of the fistulous track by MRI is mandatory. FT is the commonest procedure performed for the treatment of the low CPF, namely the subcutaneous, the intersphincteric and the low transsphincteric fistula that involves less than $30 \%$ of the external sphincter mass. Relative contraindications of the procedure are Crohn's disease and pre-existing impaired continence. Initial healing rate is very high, but there is a tendency of increased recurrence by time, as a result of either incomplete identification of fistulous track branching or patient's predisposition. Incontinence after FT is of low incidence and minor severity. Partial FT can be combined with other techniques, such as "seton" placement or LIFT for the surgical treatment of the high transsphinteric, suprasphincteric and extrasphincteric fistulae. 


\section{References}

1. Eisenhammer S. Advances in anorectal surgery with special reference to ambulatory treatment. S Afr Med J 1954;28:264.

2. Parks AG. Pathogenesis and treatment of fistuila-in-ano. $\mathrm{Br}$ Med J 1961; 1:463-469.

3. Goligher JC, Ellis M, Pissidis AG. A critique of anal glandular infection in the aetiology and treatment of idiopathic anorectal abscesses and fistulas. Br J Surg 1967; 54:977-983.

4. Seow-Choen F, Nicholl RJ. Anal Fistula. Br J Surg 1992; 79:197-205.

5. Parks AG, Gordon PH, Hardcastle JD. A classification of fistula-in-ano. Br J Surg 1976;63(1):1-12.

6. Goettgens KWA, Smeets RR, Stassen LPS, Beets G, Breukink SO. Systematic review and meta-analysis of surgical interventions for high cryptoglandular perianal fistula. Int J Colorectal Dis 2015; 30:583-593.

7. de Miguel Criado J, del Salto LG, Rivas PF, del Hoyo LF, Velasco LG, de las Vacas MI, Marco Sanz AG, Paradela MM, Moreno EF. MR imaging evaluation of perianal fistulas: spectrum of imaging features. Radiographics 2012; 32(1):175-194

8. Tolan DJ. Magnetic resonance imaging for perianal fistula. Semin Ultrasound CT MR 2016; 37:313-22.

9. Thipphavong S, Costa AF, Ali HA, Wang DC, Brar MS, Jhaveri KS. Structure reporting of MRI for perianal fistula. Abdominal Radiol 2018; doi: 10.1007/s00261-018-1839-y.

10. De Groof EJ, Cabral VN, Buskens CJ, Morton DG, Hahnloser D, Bemelman WA and of the behalf of the research committee of the European Society of Coloproctology. Systematic review of evidence and consensus on periananl fistula: an analysis of national and international guidelines. Colorectal Dis 2016; 18:0119-34.

11. Murad-Regadas SM, Regadas FS, Rodrigues LV, Holanda Ede C, Barreto RG, Oliveira L. The role of 3-dimensional anorectal ultrasonography in the assessment of anterior transsphincteric fistula. Dis Colon Rectum 2010; 53:1035-1040.

12. Subasinghe D, Samarasekera DN. Comparison of peroperative endoanal ultrasonography with intraoperative findings for fistula in ano. World J Surg 2010; 34:1123-1127.

13. Garcés Albir M, García Botello S, Esplapez Valero P et al. Evaluation of three-dimensional endoanal endosonografy of perianal fistulas and correlation with surgical findings. Cir Esp 2010; 87:299-305.

14. Garces-Albir M, Garcia-Botello AG, Esclapez-Valero P, SanahujaSantafe A, Raga-Vazquez J, Espi-Macias A, Ortega-Serano J. Quantifying the extent of fistulotomy. How much sphincter can we safely divide? A three-dimentional endosonographic study. Int $\mathbf{J}$ Colorectal Dis 2012; 27:1109-1116.

15. Murad-Regadas SM, Regadas-Filho FSP, Holanda EC, Veras LB, Vilarinho AS, Lopes MS. Can three-dimentional anorectal ultrasonography be included as a diagnostic tool for the assessment of anal fistula before and after surgical treatment? Arq Gastroenterol 2018; 55(Suppl 1):18-24.

16. Quah HM, Tang CL, Eu KW, Chan SY, Samuel M. Metaanalysis of randomized clinical trials comparing drainage alone vs primary sphincter-cutting procedures for anorectal abscessfistula. Int J Colorectal Dis 2006; 21:602-609.

17. Williams JG, Farrands PA, Williams AB et al. The treatment of anal fistula: ACPGBI position statement. Colorectal Dis 2007; 9(Suppl 4):18-50.

18. Steele SR, Kumar R, Feingold DL, Rafferty JL, Buie WD. Practice parameters for the management of perianal abscess and fistula-in-ano. Dis Colon Rectum 2011; 54:1465-1474.

19. Hamalainen KP, Sainio AP. Cutting seton for anal fistulas: high risk of minor control defects. Dis Colon Rectum 1997; 40:1443-1446.

20. Garcia-Aguilar J, Belmonte C, Wong DW, Goldberg SM, Madoff RD. Cutting seton versus two-stage seton fistulotomy in the surgical management of high anal fistula. Br J Surg 1998; 85:243-245.

21. Zbar AP, Ramesh J, Beer-Gabel M, Salazar R, Pescatori M. Conventional cutting vs. internal anal sphincter-preserving seton for high trans-sphincteric fistula: a prospective randomized manometric and clinical trial. Tech Coloproctol 2003; 7:89-94.

22. Williams JG, MacLeod CA, Rothenberger DA, Goldberg SM. Seton treatment of high anal fistulae. Br J Surg 1991; 78 1159-1161.

23. Lindsey I, Smilgin-Humphreys MM, Cunningham C, Mortensen NJ, George BD. A randomized, controlled trial of fibrin glue vs. conventional treatment for anal fistula. Dis Colon Rectum 2002; 45:1608-1615.

24. Tasci I, Erturk S, Alver O. Coring-out fistulectomy with a newly designed 'fistulectome' for complicated perianal fistulae: a retrospective clinical analysis. Colorectal Dis 2013; 15(7): e396-401.

25. Abcarian AM, Estrada JJ, Park $\mathbf{J}$ et al. Ligation of intersphincteric fistula tract: early results of a pilot study. Dis Colon Rectum 2012; 55:778-782.

26. Ortiz H, Marzo J, Ciga MA et al. Randomized clinical trial of anal fistula plug versus endorectal advancement flap for the treatment of high cryptoglandular fistula in ano. Br J Surg 2009; 96:608-612.

27. Mitalas LE, Gosselink MP, Zimmerman DD, Schouten WR. Repeat transanal advancement flap repair: impact on the overall healing rate of high transsphincteric fistulas and on fecal continence. Dis Colon Rectum 2007; 50:1508-1511.

28. Perez F, Arroyo A, Serrano P et al. Randomized clinical and manometric study of advancement flap versus fistulotomy with sphincter reconstruction in the management of complex fistulain-ano. Am J Surg 2006; 192:34-40.

29. Soltani A, Kaiser AM. Endorectal advancement flap for cryptoglandular or Crohn's fistula-in-ano. Dis Colon Rectum 2010; 53:486-495.

30. Schouten WR, Zimmerman DD, Briel JW. Transanal advancement flap repair of transsphincteric fistulas. Dis Colon Rectum 1999; 42:1419-1422.

31. Ellis CN, Clark S. Fibrin glue as an adjunct to flap repair of anal fistulas: a randomized, controlled study. Dis Colon Rectum 2006; 49:1736-1740.

32. Swinscoe MT, Ventakasubramaniam AK, Jayne DG. Fibrin glue for fistula-in-ano: the evidence reviewed. Tech Coloproctol 2005; 9:89-94.

33. Schwandner O, Stadler F, Dietl O, Wirsching RP, Fuerst A. Initial experience on efficacy in closure of cryptoglandular and Crohn's transsphincteric fistulas by the use of the anal fistula plug. Int J Colorectal Dis 2008; 23:319-324.

34. Ellis CN, Rostas JW, Greiner FG. Long-term outcomes with the use of bioprosthetic plugs for the management of complex anal fistulas. Dis Colon Rectum 2010; 53:798-802.

35. Lauretta A, Falco N, Stocco E, Bellomo R, Infantino A. Anal Fistula Laser Closure: the length of fistula is the Achilles' heel. Tech Coloproctol 2018; 22(12):933-939.

36. Terzi MC, Agalar C, Habip S, Canda AE, Arslan NC, Obuz F. Closing Perianal Fistulas Using a Laser: Long-Term Results in 103 Patients. Dis Colon Rectum 2018; 61(5):599-603.

37. Wilhelm A, Fiebig A, Krawczak M. Five years of experience with the FiLaCTM laser for fistula-in-ano management: long-term follow-up from a single institution. Tech Coloproctol 2017; 21(4):269-276.

38. Cavanaugh M, Hyman N, Osler T. Fecal incontinence severity index after fistulotomy: a predictor of quality of life. Dis Colon Rectum 2002; 45:349-353.

39. Garcia-Aguilar J, Belmonte C, Wong WD, Goldberg SM, Madoff RD. Anal fistula surgery. Factors associated with recurrence and incontinence. Dis Colon Rectum 1996; 39:723-729.

40. Jordan J, Roig JV, Garcia-Armengol J, Garcia-Granero E, Solana A, Lledo S. Risk factors for recurrence and incontinence after anal fistula surgery. Colorectal Dis 2010; 12:254-260.

41. Amato A, Bottini C, De Nardi P, Giamundo P, Lauretta A, Realis Luc A, Tegon G, Nicholls RJ; Italian society of colorectal surgery. Evaluation and management of perianal abscess and anal fistula: a consensus statement developed by the Italian Society of 
Colorectal Surgery (SICCR). Tech Coloproctol 2015; 19(10): 595-606.

42. Ho KS, Tsang C, Seow-Choen F, Tang CL, Heah SM, Eu KW. Prospective randomized trial comparing ayurvedic cutting seton and fistulotomy for low fistula-in-ano. Tech Coloproctol 2001; 5:137-141

43. Westerterp M, Volkers NA, Poolman RW, van Tets WF (2003) Anal fistulotomy between Scylla and Charybdis. Colorectal Dis 2003; 5:549-551.

44. Davies M, Harris D, Lohana P et al. The surgical management of fistula-in-ano in a specialist colorectal unit. Int J Colorectal Dis 2008; 23:833-838.

45. Cariati A. Fistulotomy or seton in anal fistula: a decisional algorithm. Updates Surg 2013; 65:201-205.

46. van der Hagen SJ, Baeten CG, Soeters PB, van Gemert WG Long-term outcome following mucosal advancement flap for high perianal fistulas and fistulotomy for low perianal fistulas. Recurrent perianal fistulas: failure of treatment or recurrent patient disease? Int J Colorectal Dis 2006; 21:784-790.

47. Sugrue J, Nordenstam J, Abcarian H, Bartholomew A, Schwartz JL, Mellgren A, Tozer PJ. Pathogenesis and persistence of cryptoglandular anal fistula: a systematic review. Tech Coloproctol 2017; 21:425-432.

48. Visscher AP, Schuur D, Roos R, van der Mijnsbrugge GJH, Meijerink WJHJ, Felt-Bersma RJF. Lonf-term follow-up after surgery for simple and complex cryptoglandular fistulas: fecal incontinence and impact on quality of life. Dis Colon Rectum 2015; 58:533-539.

49. Chatterjee G, Ray D, Chakravartty S. Partial fistulotomy and multiple setons in high anal fistulae. Indian J Surg 2009; 71: 218-220.

50. Durgue V, Perek A, Kapan M, Kapan S, Perek S. Partial fistulotomy and modified cutting seton procedure in the treatment of high extrasphincteric perianal fistulae. Dig Surg 2002; 19:56-58

51. Fung AKY, Card GV, Ross NP, Yule SR. Operative strategy for fistula-in-ano without division of the anal sphincter. Ann R Coll Surg Engl 2013; 95:461-467.

52. Schultze B, Ho YH. Management of complex anorectal fistulas with seton drainage plus partial fistulotomy and subsequent ligation of intersphincteric fistula track (LIFT). Tech Coloproctol 2015; 19:89-95. 